\title{
Some reflections on human identity in the Anthropocene
}

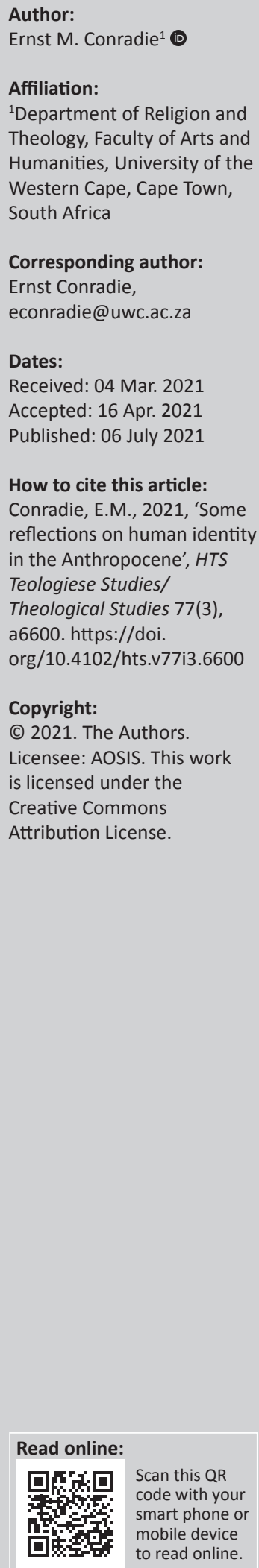

This article observes that both the similar and the dissimilar are of ethical importance in discourse on human identity. There is a need for a common humanity and to guard against domination in the name of difference - precisely by recognising the otherness of the other. This also applies to reflections on what it means to be human in the age of the human, namely the Anthropocene. A survey is offered of how this tension between the similar and the dissimilar plays itself out in the work of five theorists, namely Dipesh Chakrabarty, Clive Hamilton, Dona Harraway, Michel Serres and Kathryn Yusoff. On this basis, six tentative conclusions are offered: (1) Despite the appropriate ethical emphasis on difference and otherness, the quest for the universal in the particular cannot be readily abandoned. (2) Such a sensitivity for the universal in the particular needs to be extended to a recognition of the way in which an integrated earth system functions. (3) The ethical emphasis on difference and otherness should be extended to non-human animals. (4) Human dignity and the 'integrity of creation' are not necessarily inversely proportioned. (5) Relations may well have an ontological priority over individuals. (6) Identity need not be constituted by the distant past or the immediate presence as if continuity over time forms a guarantee for a sense of identity.

Contribution: This article explores a core question in discourse on the Anthropocene, namely 'What does it mean to be human in the age of humans?' It compares the views on human identity of five theorists, namely Dipesh Chakrabarty, Clive Hamilton, Dona Harraway, Michel Serres and Kathryn Yusoff and on this basis offers six observations to take the debate forward.

Keywords: Anthropocene; Dipesh Chakrabarty; Clive Hamilton; Dona Harraway; human identity; Michel Serres; Kathryn Yusoff.

\section{The similar and the dissimilar}

Two contrasting hermeneutical insights govern discourse on identity, also within the context of Christian theology. On the one hand, any use of the term risks some forms of hegemony. To identify features of identity is to enforce some forms of similarity amidst difference. The very word 'identify' (= idem facio) means to make similar what is dissimilar. ${ }^{1}$ It comes as no surprise that identity politics is often narrow-minded and reactionary. Those campaigning for cultural identity often assume an essentialised and fossilised manifestation of culture and employ that to exclude others from land, resources, jobs and their own heritage. The same applies to an emphasis on even a quest for Christian identity (see Conradie 2005b), Anglican identity, Catholic identity, Lutheran identity, Reformed identity and so forth (see eds. Conradie \& Klaasen 2014).

On the other hand, it is not possible to even recognise difference or otherness without some points of comparison, without spotting the similar in the dissimilar - which Aristotle claimed is the mark of poetic genius. Both these insights play a significant role in ethical discourse. It is the similarity of all humans as a species that enables an emphasis on inalienable human dignity, 'universal' human rights, a global ethic and a common critique of racism, patriarchy and heteronormativity. At the same time, the ethical emphasis on difference, otherness, hybridity and liminality marks many contemporary critiques against cultural, religious and other forms of assimilation and domination, treating the other as merely an extension of oneself or one's own interests. The irony is that such domination, namely domination in the name of difference, is made possible by an emphasis on difference too. 'In the name' here signals a false, hegemonic imposition of differences of class, gender, race, ethnicity, culture, sexual orientation and so forth.

1.See already Conradie (1992) and my proposal on the role of doctrinal constructs in biblical interpretation (Conradie 2010 ).

Note: Special Collection: New Landscapes in Identity: Theological, Ethical and Other Perspectives, sub-edited by John Klaasen (University of the Western Cape). 
This is no new debate. It is as old as the medieval conflict between 'realists' (maintaining that 'universal' ideas have an ontological priority) and 'nominalists' (maintaining that general categories are nothing but names given to particular entities). These two insights may be dialectically related, as is also illustrated by the tension between empirical science (with an eye to what is different) and the attempt to formulate general laws, even a 'theory of everything' (with an eye to what may be the same).

For me, the social significance of this tension was best captured in a talk by Christopher Duraisingh in Stellenbosch around 1991, in other words, just after the end of the Cold War, the so-called 'end of history'. Duraisingh observed a resurgence of 'narrow group identities'. This is spurred on by splinter groups that sense that large structures, such as the United Nations, the African Union, the European Union or the World Council of Churches, in the interest of maintaining global peace, will not address their particular local concerns. They cannot work for the common good if their interests are being undermined in the name of the common good. They tend to equate identity with belongingness (local, tribal, national or religious origin). However, they are not large or powerful enough to make an impact on such larger structures either. They, therefore, opt to focus on their local struggles, also by military means, typically in the name of cultural identity. In response, others become concerned about the conflict that erupts from the narrowness of such group identities and therefore emphasises the need for global cooperation and world peace. It is striking that discourse on a global ethic also emerged in the early 1990s, leading to the 'Declaration on a Global Ethics' by the Parliament of World Religions in 1993 and the Earth Charter in 2000 (see Conradie 2003). Of course, such efforts only reinforce such narrow group identities.

\section{On being human: Understanding the underlying problem}

In this contribution, I will explore the significance of these two contrasting insights for discourse on the Anthropocene where humans are said to have become a 'geological force of nature'. Especially in the natural sciences, the emphasis on an integrated Earth system in the singular, that is, the interplay between the cryosphere, the hydrosphere, the atmosphere and the biosphere, is regarded as definitive of the Anthropocene. However, the very term Anthropocene is highly contested as, for example, it seems to put the blame for anthropogenic climate change on all human beings. In the language of the IPCC, there is indeed a common but then differentiated responsibility to address climate change.

Many scholars raise the question about the identity of this presumed 'Anthropos'. Whose Anthropocene is it then ${ }^{2}$ Is this 'human' not all too white, male, affluent and more or less Anglo Saxon? Is the real problem not domination in the name of differences of class so that the new geological epoch is best understood as the 'Capitalocene', marking the impact of capitalism on the earth system (see ed. Moore 2016)? Or is the underlying problem consumerism (marked by the 'great acceleration' since 1945), where the affluent, the middle class and the poor alike aspire, in the name of difference, to more of the same, that is, to adopt the lifestyles of the so-called consumer class (see McNeill \& Engelke 2014)? Is there any substantial difference between the carbon footprint of capitalist and socialist economies? Put differently, is this a species problem (human identity in comparison with other species) or a class problem? Should the emphasis be that we are all together in the same proverbial boat, on course towards a shared catastrophe or on the distinction between the upper and the lower decks of that boat? Or in Christian terms: Should the emphasis be on the Pauline and Lutheran insight that we are all sinners - or should we insist, together with liberation and feminist theologies, on a clear distinction between perpetrators and victims, between oppressors and the oppressed, between those who are sinners and those who are sinned against? ${ }^{3}$

Chakrabarty (2009) explained the widespread resistance against such 'species-thinking':

... does not the talk of species or mankind simply serve to hide the reality of capitalist production and the logic of imperial ... domination that it fosters? Why should one include the poor of the world - whose carbon footprint is small anyway - by use of such all-inclusive terms as species or mankind when the blame for the current crisis should be squarely laid at the door of the rich nations in the first place and of the richer classes in the poorer ones? (p. 216)

Such resistance against 'species-thinking', lumping all human beings under the same category, is understandable as this is exactly the opposite of the direction in which the humanities have been going, notably in the North Atlantic context, where the emphasis has been on difference and otherness, not on identity or any 'universal' categories, in order to undermine any hegemony by demonstrating not only an irreducible plurality but also the multiple inequalities and forms of domination in the name of such difference. Moreover, as Ricoeur (1995) argued in Oneself as Another, identity (the individual or collective self) does not imply sameness. Identity cannot be established through introspection but only through the longer route of the other (one definition of ubuntu), seeing the self as another. To recognise some forms of identity is to discover the self as a stranger. Knowing oneself, as the temple of Apollo in Delphi already indicated, is harder than what identity politics may assume. The sources of the self (Charles Taylor) are unfathomable; knowing the self requires something like knowing God (John Calvin).

Nevertheless, if the emphasis is indeed on difference, should this not lead to a recognition of markers of identity such as class and gender consciousness, or cultural identity 3.See Park and Nelson (2001) and my discussion in Redeeming Sin? (Conradie 2017:143-148). 
amongst the marginalised, for example, indigenous communities? Does this not then prompt elitist notions of identity amongst the affluent, for example, in terms of 'conspicuous consumption'? Or, inversely, should such a recognition prompt a quest to overcome such differences of class? Why should some differences be maintained and others not?

Strangely, such an emphasis on difference does not necessarily apply to the humanities outside the North Atlantic - where a common humanity (against racial divides), the inalienable dignity of all human beings (against various forms of oppression) and (in Asia) 'integral thinking' (against Western dualities) have typically been stressed alongside an emphasis on difference. Difference is important in order to resist hegemony and domination but it can inadvertently backfire to allow self-marginalisation. Remarkably, the universality of the genetic code nevertheless gives rise to a plurality of species, specimens, languages and cultures (Serres 2018:210). As Serres (2018:213) observed, a recognition of the universal does not necessarily give rise to uniformity, only 'stupid force' can enforce hegemony and this is always unsuccessful. The singularity of the big bang generates, gives rise to, makes all the difference. Whilst globalisation opposes difference, the universal encourages it. 'Everything dies from uniformity' (Serres 2018:218). He (2018) adds that:

$[A] \mathrm{rmed}$, the strong boast about spreading their peculiar ways to the farthest distances: masters in the morning but dead beat in the afternoon. The weak trust in the Universal luxuriously varied across space and time. (p. 219)

To evade such species, thinking is far from easy and far from innocent. A lot is at stake. Typically, an ethical emphasis on otherness and difference calls for ethics of responsibility, as is illustrated in the oeuvres of Paul Ricoeur, Emanuel Levinas and Jacques Derrida. But can one emphasise human responsibility without an appreciation for human dignity? And can one emphasise human dignity without an appreciation for the intrinsic worth of each human being and all human beings? On what is such dignity based? This is tricky at least not because of attempts to avoid the religious rationale, namely being created 'in the image and likeness of God' which presumably does not apply to other species. To base a sense of human dignity on any specific human characteristic (rationality, language, symbolic behaviour, labour, artistic ability) exacerbates the problem of using anthropocentric criteria. This is not innocent because human eating patterns are based on such distinctions. Why else would a society condone eating chickens but not (human) children? Or why would vegetarians condone eating chickpeas but not chickens? Typically, it is the intrinsic worth of humans that is used as a criterion to guide cultural patterns. If the intrinsic worth of other forms of life is acknowledged, then the equal intrinsic worth cannot be affirmed without calling into question such eating patterns. If intrinsic worth is graded (which is the obvious solution), this again raises the question what criterion is used for such gradation. Complexity? Does such a criterion not typically remain hierarchical, indeed anthropocentric too? (see Conradie 2019).

Moreover, once a graded intrinsic worth is acknowledged to distinguish between species, the question emerges why such gradation is not applied amongst human beings too. How, does then one address problems regarding foetuses, infants, the severely mentally handicapped, the senile, the comatose, the terminally ill? In practice, human worth is of course graded (with salaries, privileges, benefits and burdens to match that), but legal systems in democratic societies depend on an affirmation of equal human dignity. The inalienable dignity of each and every human being, irrespective of gender, race, rank, creed or ability, is the cornerstone of any bill of human rights. This cannot be graded without bringing society in jeopardy.

Such a notion of equal human dignity rests upon a Cartesian and Kantian universalism, namely that all human beings share a common rationality that also distinguishes humans from other animals. However, such a (hypothetical) universalism has been steadily undermined through the various 'turns' in the humanities and social sciences over the past century or so, including the linguistic, hermeneutical, cultural, sociological, gendered and spatial 'turns'. These turns have yielded a deeply held scepticism about such universalist assumptions and a widespread recognition of difference more than similarity, an ethical appreciation for diversity, otherness, marginality, liminality, hybridity. The fundamental objection is that the very idea of 'Man' often serves as an ideological cover for imperialist or colonialist domination by race, gender, culture, sexual orientation, class and now also species.

Nowadays, such a notion of (hypothetical) universalism can also be based on genetic continuity within the human species (despite small differences in the presence of Neanderthal and Denisovan genes). This helps to guard against crude forms of racism - which often relies on some forms of social Darwinism. But if genetic similarity is the criterion, how should the $98+\%$ continuity between humans and chimpanzees be assessed? Or, is there $70 \%$ similarity between humans and chickens? Admittedly, 1\% may make a huge difference, for example between a leaking bucket and one holding water. What would therefore count as sufficient genetic continuity to acknowledge equal intrinsic worth? Can such small genetic differences between humans not be used again to legitimise cultural elitism, racism or classism? Or should the emphasis be on the commonality of DNA and RNA? Likewise, there is a huge difference between $350 \mathrm{ppm}$ and 450 ppm of carbon dioxide in the earth's atmosphere although it constitutes only a $0.01 \%$ difference in the composition of the atmosphere.

Against this background, this essay will explore literature on human identity in the Anthropocene. It will focus on and 
contrast the contributions of five scholars, namely Dipesh Chakrabarty, Clive Hamilton, Dona Harraway, Michel Serres and Kathryn Yusoff. Except for Chakrabarty where I will focus on two important essays, only one book by each of these authors will be considered..$^{4}$ In juxtaposing their views, I hope to illuminate the underlying problem and offer some tentative perspectives in this regard.

\section{Dipesh Chakrabarty on three contrasting images of the human}

Chakrabarty is a historian of Indian descent, currently based at the University of Chicago, focussing on postcolonial and subaltern studies. He is the author of numerous books and the recipient of many awards. I will focus here on two important essays on climate change and the Anthropocene.

In a much-cited and discussed essay (see especially eds. Emmett \& Lekan 2016), entitled 'The Climate of History', Chakrabarty (2009) offered the following four theses:

- Thesis 1: Anthropogenic Explanations of Climate Change Spell the Collapse of the Age-old Humanist Distinction between Natural History and Human History.

- Thesis 2: The Idea of the Anthropocene, the New Geological Epoch When Humans Exist as a Geological Force, Severely Qualifies Humanist Histories of Modernity or Globalisation.

- Thesis 3: The Geological Hypothesis Regarding the Anthropocene Requires Us to Put Global Histories of Capital in Conversation with the Species History of Humans.

- Thesis 4: The Cross-Hatching of Species History and the History of Capital are Process of Probing the Limits of Historical Understanding.

The third of these theses is pertinent here. As a Marxist historian, Chakrabarty (2009) insists that climate change is a function of the history of capital. However, he also recognises that climate change may affect the planet for much longer than capitalism or its many mutations. He states that:

$[A]$ critique that is only a critique of capital is not sufficient for addressing questions relating to human history once the crisis of climate change has been acknowledged and the Anthropocene has begun to loom on the horizon of our present. The geologic now of the Anthropocene has become entangled with the now of human history. (p. 212)

In order to understand the significance of the Anthropocene, human history in the Holocene, with the rise and demise of empires, has to be understood in the context of the deep history of the Pleistocene. He recognises that such 'species thinking', with the concomitant danger of essentialism, goes against the grain of the humanities, where the tendency is to resist any universalising of history in order to critique multiple and multiplying modernities. He concludes with the question as to how we could relate a universal history of life with a postcolonial suspicion of the universal (Chakrabarty 2009:220). He comments that 'The crisis of climate change calls for thinking simultaneously on both registers, to mix together the immiscible chronologies of capital and species history' (Chakrabarty 2009:219-220).

In another essay entitled 'Postcolonial Studies and the Challenge of Climate Change', Chakrabarty (2012) identified three distinct images of the human (besides anti-humanist and post-humanist views):

... the universalist-Enlightenment view of the human as potentially the same everywhere, the subject with capacity to bear and exercise rights; the postcolonial-postmodern view of the human as the same but endowed everywhere with ... differences of class, sexuality, gender, history and so on ... [and] the figure of the human in the age of the Anthropocene, the era when humans act as a geological force on the planet, changing its climate for millennia to come. (pp. 1-2)

These images are clearly in tension with each other. However, Chakrabarty observes that the one need not be rendered invalid or be displaced by the other. One may need to speak of humanities in the plural, but to speak of a common humanity has enabled resistance against racism and sexism. He adds that the human subject in the age of the Anthropocene is distinct from the Kantian emphasis on universality or the postmodern or postcolonial emphasis on difference (Chakrabarty 2012):

[I] $\mathrm{f}$ critical commentary on globalisation focuses on issues of anthropological difference, the scientific literature on global warming thinks of humans as constitutively one - a species, a collectivity whose commitment to fossil-fuel based, energyconsuming civilisation is now a threat to that civilisation itself. (pp. 1-2)

Indeed, climate change 'calls us to visions of the human that neither rights talk nor the critique of the subject ever contemplated' (Chakrabarty 2012:9). It does not make rights-talk or the postcolonial critique of the subject redundant, but it does elicit reflection on the unprecedented planetary scale of human impact on earth systems and not only local or regional environments (Chakrabarty 2012:9). Nevertheless, as there is no corresponding 'humanity' that can serve as a political agent to address climate change, and given the uneven impact of climate change, a politics of difference will be required to address intra-human issues of justice (Chakrabarty 2012:14). For Chakrabarty (2012:14-15), as the forces of globalisation and global warming intersect, there is a need to view human beings simultaneously through contradictory registers: as both a geological force and as political agents in an unequal, unjust world.

Chakrabarty's willingness to hold together these three contrasting, even contradictory images of being human is at least honest in the sense that it recognises the unresolved nature of the debate. 


\section{Clive Hamilton on a 'new anthropocentrism'}

In his Defiant Earth (2017), the Australian public intellectual Clive Hamilton calls for a 'new anthropocentrism' amidst the Anthropocene. ${ }^{5}$ At first sight, this appears to be an odd argument given the widespread ecological critique of anthropocentrism and the 'turn to the subject' in Western thinking. For Hamilton, the primary question is what it may mean to be human in the 'Age of Humans'. His concern is partly about the fate of humanity as the most intelligent species that the Earth has ever yielded. In an earlier book, he also wrote $A$ Requiem for the Species. For such a species to become extinct through self-destruction would be of truly cosmological significance (Hamilton 2017:116). The assumption of some may be that evolutionary history may produce other even more intelligent species. However, Hamilton is not so sure. If anthropogenic climate change would lead to the skipping of one or more ice ages, its impact may be evident millions of years into the future. As the earth is currently in a 'sweet spot' in its history following the tumultuous first billion years and an uninhabitable earth when the sun turns into a supernova in another few billion years, what has been achieved in the Holocene may never again be paralleled. He admittedly engages in 'species thinking' but argues that, from an earth system perspective, where Europe and America have gone before, Japan and then China and then India have followed and will follow.

Hamilton (2017:113) is also wary of two alternatives to the modernism that yielded the Anthropocene, namely a posthumanist relativism and an ecomodernist modification of industrialised capitalism. He resists the post-humanist characterisation of humans as 'only one of very many species and not obviously worth preserving' (with reference to a formulation by John Gray), 'mere compost to be reabsorbed' (see Haraway below), a 'mere assemblage of molecules that came together for a short time to resist entropy' (Hamilton 2017:117). He regards such positions as irresponsible:

[F]atalistic acceptance of human extinction is common amongst post-humanists whose understandable disgust at the brutality of ecological destruction delivers them into a quietism rooted in disavowal of the human project as a whole. (p. 115)

In response, he favours a chastened continuation of the modern project and the four pillars on which it is based, namely human distinctiveness, human dignity, an affirmation of 'universal' human rights and human responsibility. His position is not to be misunderstood as a normative claim that humans should be the masters of the planet but as a descriptive fact, namely that humans have become the dominant factor in earth systems, wherein humans are positioned at the centre of the world (Hamilton 2017:43). It is too late to abandon an anthropocentric standpoint as if a biocentric, ecocentric or theocentric alternative is possible.

5.This discussion draws from Conradie 2020:120-132, also 2019
Hamiton (2017:53-54) distinguished the 'new' anthropocentrism from the 'older' versions (whether biblical, Cartesian, Kantian or Marxist) that humans are entitled to use nature, either through domination and exploitation or through gratitude and stewardship. Hamilton rejects ideas of domination and of stewardship alike. The core difference between the old (Kantian) anthropocentrism and the new anthropocentrism is that the former regarded a 'humanized Earth' as inevitable and desirable, whereas the latter regards it as destructive and ambivalent at best. He explains:

$[W]$ hereas the old form declares that humankind has a special place on Earth that gives it moral dominion over nature, the new form points out that humankind has actual power to change the course of the Earth, but draws the opposite ethical conclusion. The old form claims that the Earth provides endless bounty for the sake of humans; the new form believes that the Earth will not provide bounty unless humans take care of it. Instead of concluding that humans are free to do whatever we want on a passive Earth, the new anthropocentrism insists that on an active and fractious Earth, humans are not free to do whatever we want but must restrain ourselves and restrict what we do. The old form was humanist because human destiny was thought to lie in human hands; the new is an anti-humanist anthropocentrism because the destiny of humans now lies as much in the hands of 'Gaia' as in our own. ... The new anthropocentrism puts itself outside the usual debate over values, including the notion of the intrinsic value. It is not a question of what does and does not have value; it is an approach to the whole. (pp. 54-55)

Hamilton's argument for a 'new anthropocentrism' is not only critically juxtaposed to other positions, it is also constructive. It recognises the significance of the emergence of humanity in the evolution of species. What kind of species is this that is able to wield such power? Instead of cutting humans down to size by insisting on inter-species dependence in a flat-land of entanglement, he suggests that the Anthropocene indicates that humans are not just another species (Hamilton 2017:95). In a move reminiscent of Heidegger, Hamilton (2017:99) argued that humans 'stand out' from nature as a whole. Humans are indeed embedded in nature, but this both constrains and allows for human agency and subjectivity. The Anthropocene thus requires an anthropology that does not deprive unique (i.e. intentional) human agency but recognises human distinctiveness within networks (Hamilton 2017:101). The greatness of the modern project lies in combining freedom from oppression with power over nature through using science and technology and the institutions that mobilised them. It is not only our contemplative ability that characterises the human species but also our ability to transform the earth (Hamilton 2017:119). The task that confronts humanity now is to use such power to pacify and protect the Earth in order not to destroy it (Hamilton 2017:110-11) - or to be destroyed by it.

\section{Donna Haraway on being and making compost}

Donna Haraway is Distinguished Professor Emerita in the History of Consciousness at the University of California, Santa 
Cruz. In her book Staying with the Trouble (2016), she proposes the term Chthulucene in order to emphasise, in the subtitle of the book, the need for 'making kin' (instead of making babies Haraway 2016:6). Although she agrees to use the term Anthropocene, but then sparingly, her critique is stringent:

[T]he story of Species Man as the great phallic humanising and modernising Adventure, where man, made in the image of a vanished god, takes on superpowers in his secular-sacred ascent, only to end in tragic detumescence, once again. (p. 47)

The term Chthulucene is a compound of two Greek roots khthon (earthlings, in, of or under the earth and seas) and kainos (the new that has arrived, a thick sense of presence). She argues that 'staying with the trouble requires making oddkin; that is, we require each other in unexpected collaborations and combinations, in hot compost piles' (Haraway 2016:4). Haraway imagines Chthonic ones to be 'replete with tentacles, feelers, digits, cords, whiptails, spider legs, and very unruly hair' (Haraway 2016:2). She explores 'making kin' through various metaphors such as 'string figures', 'critters', science fiction, tentacular thinking, sympoiesis, companion species, 'awash in urine' and 'communities of compost' in order to promote a way of thinking 'beyond inherited categories and capacities in homely and concrete ways' (Haraway 2016:7). The Chthulucene is therefore best understood as an emerging moral vision, 'past, present and to come':

[T] he unfinished Chthulucene must collect up the trash of the Anthropocene, the exterminism of the Capitalocene and chipping and shredding and layering like a mad gardener, make a much hotter compost pile for still possible pasts, presents and futures. (p. 57, also p. 101)

Translated into discourse on identity, Haraway's position clearly implies that identity is defined differentially, namely in relation to others with whom one interacts locally. These others include human others (e.g. in terms of gender) but also other species. She revels in describing the multiple forms of entanglement in any ecosystem. This is what 'making kin' entails. One may say that to focus on questions of identity leads to human exceptionalism, self-isolation and human alienation from the soil from which we come from. Identity can only be discovered by focussing on otherness and by engaging with such others through intertwined chtonic relationships. At best, humans make rich compost and do not allow cancerous economic growth (her critique of the Capitalocene): 'We are humus, not Homo, not Anthropos; we are compost, not posthuman' (Haraway 2016:55) and 'We are compost, not posthuman; we inhabit the humusities, not the humanities. Philosophically and materially, I am a compostist, not a posthumanist' (Haraway 2016:97).

Admittedly, one is left to wonder whether earthworms are not better at making compost and how the kind of symbolic thinking in which she so richly engages enriches the soil. Yet, her rhetoric hinges upon an emphasis on continuity with other species, thus sameness is observed more than differences. Her answer is that 'thinking people must learn to grieve-with' (Haraway 2016:38). Being compost requires species differentiation and therefore some identification but the entanglement of species also implies a common situatedness.

\section{Michel Serres on becoming human}

The late French philosopher Serres (1995) is best known for his The Natural Contract in which he proposes the need for a 'natural contract' that extends the social contract because the world is typically absent from the latter. The natural contract implies for him the metaphysical recognition that collective decisions operate and is embedded in the same natural world as all others. The natural contract acknowledges an equilibrium between human power and the forces of the world, just as a social contract recognises equality between human signatories (Serres 1995:45-46).

Because of the recent translation of his work into English, his influence is spreading rapidly. This is exemplified by Hominescence, first published in French in 2001 and now available in English (2019).

In Hominescence, Serres explores a critical moment in human history where, as stated by Steven Brown on the back cover, 'we cease to be natured and become forces of naturing'. For Serres (2019:10), hominescence is a stage in the process of hominisation that has taken place by our own doing but we do not yet know what form of humanity it is going to 'produce, magnify or murder'. It may be giving birth to another humanity and 'Nothing can arouse our concern more than this arrival' (Serres 2019:11). Serres' almost anecdotal writing is richly textured, often poetic, hard to capture and impossible to summarise. For discourse on human identity, it would suffice to highlight the following insights:

For Serres (2019:12), hominescence is an incomplete process of becoming human that entails a bouquet of bifurcations along evolutionary tracks. The term is proposed in order to emphasise the continuity between nature and culture. Nature signifies giving birth and that entails setting up a new equilibrium far from a former stability and not the preservation of some order (Serres 2019:33). This process includes the birth of life itself from what is inert, the emergence of bacteria, vegetative and animal evolution, hominid and later hominin evolution and the emergence of culture ('nature itself pursued by other means'). Serres builds on the Galilean insight that nature is written in a mathematical language. He argues that this also holds for culture on condition that the role of algorithms, letters and (musical) notes are also recognised. Each of these seem to be preexistent and become incarnated in the living world. The transcendent (Yahweh, the Logos) realises itself in the immanent (Serres 2019:59). Human nature is far from stable (illustrated with increases in human height and longevity over the last few 100 years - 2019:17-18) and with the advent of biotechnology and artificial intelligence is prone towards new bifurcations. Throughout this process of hominescence, we have been creating an environment wherein feedback loops have reconstructed our own bodies that again shaped 
this environment (Serres 2019:37). In this way Serres emphasises the continuity between the so-called hardsciences and the humanities.

The book offers a description of what these shifts entail with reference to the emergence of modern medicine and its impact on our bodies, industrial pollution, nuclear weapons, the decentralisation of agriculture, the dialectic amongst speaking, writing, printing and visual communication, biotechnology (dubbed artificial selection) and artificial intelligence. In the opening chapter, he describes this shift in terms of four deaths: individual death, the death of a civilisation, the now possible global death of humanity (symbolised by the date 06 August 1945 - Hiroshima) and the death of elementary cells, embedded in the very process of life by breathing. In one of his typical aphorisms: 'Thanks to oxygen, I breathe, and its rust destroys me. What kills me comforts me' (Serres 2019:5).

\section{These shifts also imply a change in ethics}

[O]ur old moralities trained the will to live within the inevitable constraints of suffering and early death; the new morality emanates from the freedom acquired against them. We are in part becoming responsible for the duration of our lives and for their quality. (Serres 2019:22)

A new morality of immortality is emerging: taking responsibility for the health of our own bodies, pushing back the executionary date of our mortality (Serres 2019:23).

Serres recognises the paradox that innovation (newness, otherness, difference) is the outcome of repetition through training to do the same thing over and over again. This applies to research, sport, language acquisition, music, carpentry and possibly also to random mutations - which is only possible given the repetition of the same sequence (Serres 2019:32). This suggests a subtle critique of classical Darwinism: it is inadaptation that allows for evolution: a perfectly adapted species has no need for change (Serres 2019:33).

For Serres, the latest phase of hominescence is one in which humans attain the characteristics of omniscience and omnipotence. Ironically, God then inherits all the attributes that humanity despises in itself: weakness, victimhood, fragility, persecution and abandonment. God becomes less universal than homo universalis (Serres 2019:127). One may say that human identity thus remains inversely proportioned to being divine. Ironically, in the name of difference, unanimity is being fabricated - to the point of social engineering and mass media marketing that tend to fabricate politics, morality and religion as well. Homo faber shapes homo politicus (Serres 2019:218).

Serres (2019:261) concluded that hominescence implies that the old humanism, thirsting for beauty amidst deprivation, plundering, misery and melancholy, have vanished with no hope of any return. The humanism of the Renaissance did not end injustice and perpetuated barbarity. His moral vision is one of becoming human as it was for the first time, with the aid of available technologies, in order to establish peace on the earth for all through a symbiotic natural contract (Serres 2019:249). Peace is not an aim in itself as working for peace is only a goal in times of conflict. Once there is peace, what should we then do? For Serres (2019:262), hominescence implies that 'Everything remains to be done, reinvented, brought about, organized, founded, mediated on, thought about ...'.

\section{Kathryn Yusoff on a billion black Anthropocenes}

There is, as noted above, an ongoing debate on naming the 'Anthropocene' as such. This already implies a two-fold judgement: It not only indicates human distinctiveness but also assumes that generalisations about human beings - across divides of geography, race, gender, class, culture, language and religion - are appropriate - even if this tends to erase histories of patriarchy, white supremacy and (settler) colonialism, dispossession and oppression. One pertinent example where such assumptions are questioned is the work of Kathryn Yusoff. In A Billion Black Anthropocenes or None (2018), she traces the colour line of discourse on the Anthropocene, with reference to issues of race, gender and sexual orientation. As noted above, those who agree that a new marker of geological time is appropriate to distinguish the Holocene from what is following it, given humanity's stratigraphic imprint, remain deeply divided over whether this is best named as the Anthropocene. Such debates should be welcomed, but only if the basic premise is granted, namely that (some) humans have become a geophysical force on a planetary scale.

Yusoff (2018) resisted alternatives (alter-cenes) to the Anthropocene but insists on a redescription in terms of extractive colonialism as the racialised assemblage from which it emerged (p. 61). She understands blackness as a 'historically and intentionally enacted deformation in the formation of subjectivity, a deformation that presses an inhuman categorization and the inhuman earth into proximity'. (Yusoff 2018:xii). It is this proximity of black bodies to harm as a result of such intimacy that she refers to as 'black Anthropocenes'. This usage (deliberately) disables communication between the natural sciences and inhuman geography (Yusoff's discipline) given its critique of 'white geology'. Geology is hardly immune to human power relations, as it is so deeply intertwined with extractive industries in terms of funding, labour, surveying and technology (Yusoff 2018:13).

It is, therefore, crucial to expose assumptions about Anthropocene universality as disguising subjugation in terms of gender and especially race. If humanity has become a geological force of nature, this is racialised through slave labour on mines, plantations and factories. For Yusoff (2018:82), the Anthropocene is, therefore, materially 
constructed as anti-Blackness, built on the labour of those excluded from its wealth accumulation but who nevertheless have to bodily absorb its waste products as toxicity and confront the storms unleashed.

Yusoff (2018) is irked by male portrayals of the Anthropocene seeing it as the outcome of technological ingenuity (dating it back to the industrial revolution) or of the 'great acceleration' of production and consumption since World War II. Her critique is devastating:

[T]his is the tale of entrepreneurship of a few white men transforming the world with their ingenious creations or of a political economy that is aggressively sutured to the earth's processes via the lifeblood of fossil fuels. So the explorer as hero (Columbus) is replaced by the inventor as hero (Watt and his engine) in the progress narrative of Man as the agentic centre and authority of power, cut with some European genius myths to rarefying the white male subject and his imperial intellectualism. (p. 39)

She argues that:

[T] he colonial assumption for the responsibility for and of the world is articulated anew as the white man's burden - a paternalism that is tied to a redemptive narrative of saving the world from harm on account of others whilst maintaining the protective thick skin of innocence. (p. 27)

The advent of the Anthropocene is not merely to be associated with the side effects of (capitalist) industrial rapacity (in terms of production) and affluenza (in terms of consumption). The underlying problem is deeply embedded in the history of Western imperialism, white supremacy, patriarchy and heteronormativity. Discourse on the Anthropocene itself therefore needs to be decolonised, or else will be subject to the critique of a racialised territorialisation of the Earth and branded as 'white, colonial geology' (Yusoff 2018:103, 105). It may be relevant to instruct individuals on their carbon footprint and to challenge the corporate greed of the fossil fuel industry and its shareholders, but this does not yet address the structural problem of the reliance of the global economy on fossil fuels as the major source of energy - black oil and coal that functionally replaced the reliance on black slave labour (Yusoff 2018:6).

\section{Some tentative conclusions}

What, then, does it mean to be human in the 'age of humans'? In terms of discourse on identity as sketched above, I suggest the following conclusions.

Firstly, despite the appropriate ethical emphasis on difference and otherness, the quest for the universal in the particular cannot be readily abandoned. Humanism is based on the pillars of human dignity, human rights and a common human responsibility. Any attempt to qualify such commonality opens the door to re-impose subjugation in terms of gender, race, class, caste or age, that is, to treat some humans as if they are not fully human. Attempts to articulate the universal are necessarily provisional, hypothetical and subject to critical interrogation but are also inevitable and ethically required.

Secondly, such a sensitivity for the universal in the particular needs to be extended beyond a mere vision for the common good to a recognition of the way in which an integrated earth system functions. Holism may be epistemologically flawed and arrogant (no one can see the whole), but discourse on the Anthropocene at least suggests that a failure to regard the interplay between planetary sub-systems is proving disastrous.

Thirdly, the ethical emphasis on difference and otherness should be extended to non-human animals. Animals should not be treated as extensions of humans, as if they were humans, not even in ways that the phrase the humane treatment of animals' suggests. The question is not whether they have intrinsic worth (that should be obvious), or even whether they have equal intrinsic worth. Instead, the problem is one of defining the criteria for recognising the ethical significance of differences between humans and other animals, insects, plants, bacteria and other non-living things. All too often, such criteria remain anthropocentric as they are based on human exceptionalism and therefore supremacy. Again, a lot is at stake here, not least in terms of eating practices and euthanasia. Why can human supremacy be maintained but not white supremacy? Why can non-living things be defined in terms of the living, whilst the term 'non-whites' has to be resisted? If blacks should not be treated 'as if they were white', should animals be treated 'as if they were humans'? Again, if there is a qualitative difference amongst humans, animals, plants and things, how is such quality to be described and what prevents some humans then from imposing the underlying criteria also amongst humans? This remains unresolved.

Fourthly, as I have argued before, human dignity and the 'integrity of creation' are not necessarily inversely proportioned (Conradie 2004). A recognition of difference allows us to appreciate and value what is exceptional, not only in humans. However, this is only possible if the underlying ecosystems that allow such differentiation to emerge can flourish. Value richness (based on complexity and exceptionalism, e.g. a prize-winning cheese) is important, but so are instrumental value (the milk provided by cows) and systemic value (oxygen and grass for the cows to feed on). Value richness may well be inversely proportioned to systemic value (see Rolston 1988).

Fifthly, relations may well have an ontological priority over individuals. An individual is a concretisation of a particular set of relations in time and place. As Serres (2019:227) has it, 'I am not me, like a point, and fixed, but the cloud of people possibly close to me'. This should not be understood in a collectivist way as if my identity is constituted by my belonging to the state, the party, the church, the tribe, the community (as the notion of Ubuntu is sometimes misunderstood). This can only 
lead to fundamentalism (Serres 2019:228). Again, individuality (otherness and difference) is not inversely proportioned to a sense of belonging (sameness, repetition).

Finally, identity need not be constituted by the distant past or the immediate presence as if continuity over time forms a guarantee for a sense of identity. If notions of identity are social constructs, they are projections into the future. We are not who we are. We have to become who we are and may be. This is well expressed by the volume Becoming UWC on the history (and identity) of the institution (eds. Lalu \& Murray 2012). UWC is precisely not defined by its establishment (based on race-classification), or by courage shown during struggle against apartheid, or by its more recent success stories (Bharuthram \& Pokpas 2020), but by the ongoing attempt to make sense of the task of being a university in this particular context. My sense is that Serres' term hominescence captures a similar insight. It is not as we are all humans and have to adhere to some notion of being humane; we are embedded in a process of becoming human. The advent of the Anthropocene marks a crucial stage in this process where the death of individuals, of civilisations, of species and perhaps even of the human species is at stake.

\section{Acknowledgements \\ Competing interests}

The author declares that he has no financial or personal relationships that may have inappropriately influenced him in writing this article.

\section{Author's contributions}

E.M.C. is the sole author of this research article.

\section{Ethical considerations}

This article followed all ethical standards for research without direct contact with human or animal subjects.

\section{Funding information}

This research received no specific grant from any funding agency in the public, commercial or not-for profit sectors.

\section{Data availability}

Data sharing is not applicable to this article as no new data were created or analysed in this study.

\section{Disclaimer}

The views and opinions expressed in this article are those of the author and do not necessarily reflect the official policy of any affiliated agency of the author.

\section{References}

Bharuthram, R. \& Pokpas, L. (eds.), 2020, From hope to action through knowledge: The renaissance of the University of the Western Cape 2001-2014, UWC Press, Stellenbosch.

Chakrabarty, D., 2009, 'The climate of history: Four theses', Critical Inquiry 35(2), 197-222.

Chakrabarty, D., 2012, 'Postcolonial studies and the challenge of climate change', New Literary History 43(1), 1-18.

Conradie, E.M., 1992, 'What is an analogical imagination?', The South African Journal of Philosophy 11(4), 103-112.

Conradie, E.M., 2003, 'On a human rights culture in a global era: Some ecological perspectives', in K. Sporre \& H.R. Botman (eds.), Building a human rights culture: South African and Swedish perspectives, pp. 311-333. Högskolan Dalarna, Falun.

Conradie, E.M., 2004, 'On the integrity of the human person and the integrity of creation: Some Christian theological perspectives', in C.W. Du Toit (ed.), The integrity of the human person in the African context: Perspectives from science and religion, pp. 107-152, University of South Africa, Pretoria.

Conradie, E.M., 2005a, An ecological Christian anthropology: At Home on Earth?, Ashgate, Aldershot.

Conradie, E.M., 2005b, Christian identity: An introduction, Sun Press, Stellenbosch.

Conradie, E.M., 2010, 'What on earth is an ecological hermeneutics? Some broad parameters', in D.G. Horrell, C. Hunt, C. Southgate \& F. Stavrakopoulou (eds.) Ecological hermeneutics: Biblical, Historical, and Theological Perspectives, pp. 295-314, T.\&T. Clark, London.

Conradie, E.M., 2019, 'Could eating other creatures be a way of discovering their intrinsic value?', Journal of Theology for Southern Africa 164, 26-39.

Conradie, E.M., 2020, Secular discourse on sin in the Anthropocene: What's wrong with the world?, Lexington Books, Lanham.

Conradie, E.M. \& Klaasen, J. (eds.), 2014, The quest for identity in so-called mainline churches in South Africa, Sun Press, Stellenbosch.

Emmett, R. \& Lekan, T. (eds.), 2016, 'Whose Anthropocene? Revisiting Dipesh Chakrabarty's four theses', RCC Perspectives: Transformations in Environment and Society 16(2), 3-114.

Hamilton, C., 2015, Requiem for a species: Why we resist the truth about climate change, Routledge, London.

Hamilton, C., 2017, Defiant Earth: The fate of humans in the Anthropocene, Polity Press, Cambridge.

Haraway, D.J., 2016, Staying with the trouble: Making kin in the chthulucene, Duke University Press, Durham.

Lalu, P. \& Murray, N. (eds.), 2012, Becoming UWC: Reflections, pathways and the unmaking of Apartheid's legacy, Centre for Humanities Research, Cape Town.

McNeill, J.R. \& Engelke, P., 2014, The great acceleration: An environmental history of the Anthropocene since 1945, The Belknap Press, Cambridge.

Moore, J.W. (ed.), 2016, Anthropocene or Capitalocene? Nature, history and the crisis of capitalism, PM Press, Oakland.

Park, A.S. \& Nelson, S.L. (eds.), 2001, The other side of sin: Woundedness from the perspective of the sinned-against, State University of New York Press, New York, NY.

Ricoeur, P., 1995, Oneself as another, University of Chicago Press, Chicago, IL.

Rolston, H., 1988, Environmental ethics: Duties to and values in the natural world, Temple University Press, Philadelphia, PA.

Serres, M., 1995, The natural contract, The University of Michigan Press, Ann Arbor, MI.

Serres, M., 2019, Hominescence, Bloomsbury, London.

Yusoff, K., 2018, A billion black Anthropocenes or none, University of Minnesota Press, Minneapolis, MN. 